\title{
Pemanfaatan Jerami Jagung Yang Diinokulasi Fungi Trichoderma sp. Sebagai Pakan Kambing Kacang Dengan Tambahan Daun Gamal
}

\section{Utilization of Corn Straw Inoculated with Fungi Trichoderma sp. As a Feed for Goats with Gamal Leaf Addition}

\author{
Rosi fitriani ${ }^{1}$, Ulva Mohtar Lutfi ${ }^{1}$ \\ ${ }^{1}$ Program Studi Peternakan, Politeknik Pertanian Negeri Payakumbuh \\ Jl. Raya Negara Km. 7 Tanjung Pati, 26271, Payakumbuh \\ rosifitrianio1@gmail.com
}

\begin{abstract}
Diterima : 02 Desember 2018
Disetujui : 04 Desember 2018

Diterbitkan : o5 Desember 2018
\end{abstract}

\begin{abstract}
Abstrak: Produktivitas sebagian besar ditentukan oleh ketersediaan pakan. Populasi ternak terus bertambah karena itu juga dibutuhkan pakan lebih. Pemberian pakan yang berkelanjutan dan kualitas yang memadai adalah salah satu faktor penentu kesuksesan pertanian. Pemanfaatan pakan lokal secara optimal yaitu sebuah teknologi, menggunakan jerami jagung yang diolah dengan bantuan Trichoderma sp. Kambing kontrol diberi pakan jerami jagung $60 \%$ dan daun gamal $40 \%$ serta penambahan saka dan mineral sebanyak $2 \%$. Kambing perlakuan pakan yang diberikan adalah jerami jagung yang diinokulasi Trichoderma sp. 6o \%, daun gamal $40 \%$. Berdasarkan hasil pengamatan, dengan pemberian jerami jagung fermentasi Gliricidia daun $60 \%+40 \%$ menghasilkan rata-rata $P B B$ 95,2 g / ekor / hari sedangkan kambing kontrol menghasilkan rata-rata 35,7 gram PBB / ekor / hari. Berdasarkan pelaksanaan penelitian ini, kambing dengan fermentasi $R$ / C ratio 1,34 dan perlakuan kambing dan kontrol o,9. Ini berarti bahwa perlakuan ini cukup baik untuk dikembangkan dan diimplementasikan untuk menghasilkan keuntungan sebesar $34 \%$.
\end{abstract}

Kata Kunci : Fermentasi Jerami Jagung; Kambing Kacang; Mineral; Saka.

Abstract: The productivity of ruminants is largely determined by the availability of feed. Livestock population continues to grow to cause increasingly also feed required. Provision of sustainable feed with sufficient quality and quantity is one of the Critical Success Factor for the success of the farm. Utilization of local feed optimally ie One technology use corn straw which is processed with the help Trichoderma sp. Feeding on treatment that corn straw fermentation of $280 \mathrm{~g} /$ day of added leaves of Gliricidia as much as $311 \mathrm{~g} /$ day, while for the control of corn straw $1050 \mathrm{gr} /$ day, gliricidia leaves $730 \mathrm{~g} / \mathrm{day}$, and added brown sugar and minerals $2 \%$. Based on observations research. UN goats treated by administering fermented corn straw Gliricidia leaves $60 \%+40 \%$ UN produces an average of $95.2 \mathrm{~g} /$ head/day while corn straw goat giving control $60 \%+40 \%$ Gliricidia leaves produce an average of 35.7 grams UN/head /day. Based on the implementation of this research goat by fermentation of corn straw to feed own $R / C$ ratio of 1.34 and goats goat treatment and control o.9. This means that this business well enough to be developed and implemented for this business resulted in a gain of $34 \%$.

Keywords : Corn Straw Fermentation; Goat Beans; Mineral; Saka.

\section{Pendahuluan}

Kambing kacang termasuk kambing lokal yang memiliki potensi dan peluang untuk dikembangkan karena memiliki beberapa keuntungan di antaranya hewan ini mudah beradaptasi dengan lingkungan, dapat dipelihara di daerah kering (marjinal), kebutuhan modal lebih rendah dibandingkan hewan ternak ruminansia besar seperti sapi dan kerbau. Selain itu feses dan urinnya dapat dimanfaatkan sebagai pupuk [1].
Produktivitas ternak ruminansia sangat ditentukan oleh ketersedian pakan. Populasi ternak yang terus bertambah menyebabkan semakin bertambah pula pakan yang dibutuhkan. Produksi hijauan sangat berfluktuasi, berlimpah pada musim hujan, terjadi kekurangan saat kemarau dan pada daerah padat sumber ternak. Permasalahan yang dihadapi peternak adalah berkurangnya pakan berkualitas disebabkan adanya alih fungsi lahan. 
Penyedian pakan yang berkesinambungan dengan kualitas dan kuantitas yang memadai merupakan salah satu faktor penentu keberhasilan usaha peternakan. Strategi pemberian pakan yang efisien yaitu dengan memanfaatkan sumber daya lokal yang melimpah dan bernilai gizi yang baik.

Limbah pertanian yang potensial dimanfaatkan sebagai pakan ruminansia adalah jerami jagung. Faktor pembatas dari penggunaan jerami jagung adalah nilai nutrisi yang rendah. Upaya untuk meningkatkan nilai nutrisinya yaitu melakukan pengolahan sebelum diberikan pada ternak. Pengolahan secara biologis dengan bantuan mikroorganisme saat ini banyak dilakukan, karena ramah lingkungan. Pengolahan dengan cara biologis ini disebut fermentasi.

Namun pemberian pakan perlu dikombinasikan dengan pakan kaya sumber protein yaitu jenis leguminosa antara lain gamal. Daun gamal dipilih disamping potensinya cukup besar dan bernilai gizi tinggi juga merupakan leguminosa yang ketersediaannya kontinyu sepanjang tahun. Sedangkan jerami jagung mempunyai kandungan protein 5,56\%, serat kasar 33,58\%, lemak kasar 1,25, abu 7,28 dan BETN 52,32\% [2]. Berdasarkan dengan kandungan nutrisinya yang rendah jerami jagung perlu diolah menjadi fermentasi.

Jerami jagung yang mengalami fermentasi mempunyai nilai gizi yang lebih tinggi dari pada bahan aslinya, hal ini terjadi karena mikroba bersifat katabolik atau memecah komponen yang kompleks menjadi menjadi zat yang lebih sederhana sehingga mudah dicerna.

Pemberian jerami jagung yang difermentasi dengan inokulum Trichoderma sp. sebanyak $60 \%$ dan daun gamal $40 \%$ dengan jumlah pemberian pakan 3,5\% dari berat badan serta penambahan saka dan mineral sebanyak $2 \%$ dapat meningkatakan bobot badan kambing kacang jantan sebesar 80 gr/ekor/hari [3].

Berdasarkan hal tersebut diatas perlu disusun penelitian dengan judul "pemanfaatan jerami jagung yang diinokulasi fungi Trichoderma $S p$. sebagai pakan kambing kacang dengan tambahan daun gamal”.

Tujuan khusus dari pelaksanaan penelitian ini adalah mengetahui dampak pemberian jerami jagung dan daun gamal yang diinokulasi Trichoderma $s p$. terhadap konsumsi dan pertambahan bobot badan harian $(\mathrm{PBBH})$ kambing kacang periode pertumbuhan.

\section{Materi dan Metode}

\subsection{Waktu dan tempat pelaksanaan}

Penelitian dilaksanakan pada tanggal o3 Oktober 2016 sampai tanggal 31 Desember 2016, yang bertempat di kandang Bapak Didi Kandang Lamo.

\subsection{Alat dan bahan}

Alat dan bahan yang diperlukan dalam proses penelitian ini antara lain: kandang, sabit, sapu lidi, tempat pakan, tempat minum, karung, timbangan, tali, sekop, batu asahan, plastik dan hygrometer. Bahan yang digunakan adalah kambing kacang jantan yang perlakuan umur 7 bulan dan kambing kontrol umur satu tahun, jerami jagung, daun gamal, Trichoderma sp. saka, mineral, vitamin B-komplek injeksi, obat cacing kaplet, kapur dan desinfektan.

\subsection{Metode pelaksanaan}

Data diperoleh dari data primer dan sekunder. Data primer berdasarkan hasil pengamatan di lapangan dengan cara mengikuti secara aktif kegiatan yang berhubungan langsung dengan pemeliharaan kambing.

\subsection{Parameter}

Parameter yang diukur adalah pertambahan bobot badan harian (PBBH). Mengetahui jumlah pertambahan bobot badan hariannya dapat dilakukan dengan cara pengurangan bobot akhir dengan bobot awal yang dibagi dengan lama pemeliharaan.

\subsection{Pelaksanaan penelitian}

\subsubsection{Persiapan kandang}

Kandang disiapkan satu minggu sebelum kambing datang, kegiatan yang dilakukan antara lain pembersihan kandang dengan cara lantai dan dinding disapu dengan sapu lidi. Tempat makan, kolong dibersihkan dengan garu dan sekitar kandang dibersihkan dari sampah-sampah yang ada. Kemudian kandang disemprot dengan desinfektan baik bagian dalam maupun bagian luar, hal ini dilakukan untuk membasmi kuman penyakit.

Kandang yang digunakan adalah kandang panggung dengan bahan dari kayu, ukuran kandangnya 2 x 1,5 m. kandang yang digunakan juga mendapat sinar matahari pagi.

\subsubsection{Pengadaan kambing}

Kambing yang dipelihara dalam pelaksanaan Penelitian adalah kambing kacang jantan, kambing kacang dibeli dari peternak kambing dengan berat awal perlakuan $6 \mathrm{~kg}$ berumur 7 bulan dan kontrol berat awal $14 \mathrm{~kg}$ berumur satu tahun, melihat dari gigi susunya apakah sudah berganti atau belum. Pertumbuhan kambing jantan lebih cepat dan juga pertambahan bobot badannya lebih tinggi. Bibit kambing yang akan digemukkan harus sehat dan tidak cacat, penampilan fisiknya harus baik, bulunya harus tampak seperti basah, kakinya tegak dan besar, mata cerah dan moncongnya tumpul.

Setelah kambing datang langsung ditimbang untuk mengetahui berat awal, kemudian kambing dimandikan dan dibersihkan. Kemudian pada awal pemeliharaan kambing diberi obat cacing kaplet. 


\subsubsection{Pemberian pakan}

Pemberian pakan adalah $(3,5 \% \mathrm{BK})$ dari berat badan [4]. Kambing kontrol diberi pakan jerami jagung 60\% dan daun gamal 40\% serta penambahan saka dan mineral sebanyak $2 \%$. Kambing perlakuan pakan yang diberikan adalah jerami jagung yang diinokulasi Trichoderma sp. 6o \%, daun gamal $40 \%$. Pakan diberikan dua kali sehari yaitu jam o8.oo pagi dan 16.00 sore. Air minum diberikan secara ad libitum (tersedia terus menerus).

\subsubsection{Pencegahan penyakit}

Kandang yang bersih membuat kuman penyakit sulit berkembang. Artinya, serangan kuman pada kambing akan jarang terjadi sehingga kesehatan kambing lebih terjaga. Selain itu, kambing akan semakin nyaman berada di kandang. Oleh karenanya, sebaiknya kandang dibersihkan setiap hari. Selain membuang kotoran kambing, celah-celah kandang juga perlu dibersihkan karena kutu dan parasit lain yang sering bersarang ditempat ini.

Kandang yang lembab tentu tidak baik bagi kesehatan kambing karena kondisi ini membuat kuman penyakit mudah berkembang. Sirkulasi udara, sinar matahari terutama pagi hari juga bisa mengurangi kelembapan di dalam kandang. Oleh karena itu, kandang sebaiknya dibuat menghadap ke timur. Apabila tidak memungkinkan, atap diberi genting kaca sehingga sinar matahari bisa menembus ke dalam kandang.

Kambing yang tererang penyakit perlu dikarantina yang agak jauh agar tidak menularkan penyakitnya ke kandang lain. Kambing yang baru dibeli juga perlu dikarantina terlebih dahulu selama beberapa hari untuk memestikan kondisi kesehatannya.

Pakan berkualitas yang diberikan dalam kuantitas yang cukup akan mampu memenuhi kebutuhan kambing terhadap zat gizi. Hal itu dapat meningkatkan daya tahan tubuh kambing terhadap serangan penyakit ataupun terhadap kodisi lingkungan yang buruk.

Jenis penyakit yang biasanya menyerang kambing dapat digolongkan dalam dua kelompok yaitu penyakit menular dan penyakit tidak menular. Umumnya penyakit yang sering menyerang kambing adalah pink eye, mencret, cacingan, kudis, orf, kejang, infeksi akibat luka, dan perut kembung. Prinsip utama pencegahan penyakit adalah meningkatkan daya tahan kambing melalui kebersihan dan pemeliharaan lingkungan yang semaksimal mungkin.

\section{Hasil dan Pembahasan}

\subsection{Waktu pemberian pakan dan persentase produksi harian}

Selama pelaksanaan penelitian dilakukan pengamatan terhadap kambing yang dipelihara, yaitu terhadap pertambahan bobot badan kambing (PBB). Pengukuran pertambahan bobot badan kambing dilakukan setiap minggu, dengan menghitung PBB dari selisih minggu sesudahnya dengan minggu sebelumnya. PBB selama penelitian dapat dilihat pada tabel 1.

Tabel 1. Pertambahan bobot badan kambing kontrol dan perlakuan selama pemeliharaan 12 minggu.

\begin{tabular}{|c|c|c|c|c|}
\hline \multirow{2}{*}{ Minggu } & \multicolumn{2}{|c|}{ Kambing Kontol } & \multicolumn{2}{|c|}{ Kambing Perlakuan } \\
\hline & Bobot badan & $P B B$ & Bobot badan & $P B B$ \\
\hline Berat Awal & 6 & - & 14 & - \\
\hline II & 7 & 500 & 14,8 & 300 \\
\hline III & 7,7 & 700 & 15 & 200 \\
\hline IV & 8 & 300 & 15,5 & 500 \\
\hline V & 10 & 2000 & 14,2 & -1300 \\
\hline VI & 11 & 1000 & 14,6 & 400 \\
\hline VII & 10,3 & -700 & 15 & 400 \\
\hline VIII & 11 & 700 & 15,5 & 500 \\
\hline IX & 11,8 & 800 & 16 & 500 \\
\hline $\mathrm{X}$ & 12 & 200 & 16,3 & 300 \\
\hline XII & 14 & 1000 & 17 & 200 \\
\hline Jumlah & & 8000 & & 3000 \\
\hline
\end{tabular}

Berdasarkan data pada tabel 1 dapat dilihat bahwa pertambahan bobot badan kambing kacang perlakuan lebih tinggi dibandingkan pertambahan bobot badan kambing kontrol. PBB kambing perlakuan dengan pemberian jerami jagung fermentasi $60 \%$ + daun gamal 40\% menghasilkan rata-rata $\mathrm{PBB}$ 95,2 g/ekor/harinya sedangkan kambing kontrol pemberian jerami jagung 6o\% + daun gamal $40 \%$ menghasilkan rata-rata $\mathrm{PBB} 35,7$ g/ekor/hari. Perbedaan pertambahan bobot badan antara perlakuan dan kontrol disebabkan karena bobot badan awal kontrol dan perlakuan berbeda dari 
yang direncanakan dan juga pemberian jerami jagung yang mengalami fermentasi mempunyai nilai gizi yang lebih tinggi dari pada bahan aslinya, hal ini terjadi karena mikroba bersifat katabolik atau memecah komponen yang kompleks menjadi menjadi zat yang lebih sederhana sehingga mudah dicerna oleh ternak. Hal ini sesuai dengan pendapat [5] yang mengatakan bahwa makanan yang cukup dan sempurna dapat mempercepat terjadinya laju puncak pertumbuhan urat daging dan penimbunan lemak sehingga berdampak pada pertambahan bobot badan kambing.

Menurut [3] pemberian jerami jagung yang difermentasi dengan inokulum Trichoderma sp. sebanyak 6o\% ditambahkan daun gamal 40\% dengan jumlah pemberian pakan 3,5\% dari berat badan serta penambahan saka dan mineral sebanyak 2\% dapat meningkatakan bobot badan kambing kacang jantan sebesar 8o g/ekor/hari, dibandingkan dengan realisasi pada pelaksanaan penelitian yang dijalankan selama 90 hari menghasilkan pertambahan bobot badan rata-rata 95,2 g/ekor/hari lebih tinggi dari pada perencanaan. Namun demikian pertambahan bobot badannya lebih tinggi dari target yang diinginkan dkarenakan bobot badan kambing yang direncanakan $10 \mathrm{~kg}$ yang terlaksana adalah $6 \mathrm{~kg}$.

Penyebab PBBH kambing perlakuan lebih tinggi dari yang direncanakan salah satunya yaitu perubahan teknis pada pemberian pakan dan juga faktor umur ternak, perbedaan umur menyebabkan perbedaan kecepatan pertumbuhan, ternak yang berumur muda cenderung memiliki kecepatan pertumbuhan yang lebih tinggi dibandingkan ternak yang berumur dewasa. Dilakukan adaptasi selama 2 minggu untuk membiasakan kambing agar mau memakan jerami jagung fermentasi dan ditambahkan daun gamal, dengan kita membiasakan maka pertambahan bobot badannya juga akan meningkat. Minggu berikutnya barulah kambing perlakuan diberikan jerami jagung yang diolah menjadi fermentasi diberikan 2 kali sehari kepada kambing perlakuan. Dilihat pada tabel diatas, pada minggu 1 minggu 4 mengalamai peningkatan, Tetapi pada minggu ke-5 mengalamai peningkatan sebanyak 2 kg dikarenakan kambing sudah terbiasa memakan fermentasi jerami jagung. Begitu juga dengan baunya yang harum sehingga terasa enak dimakan oleah kambing. Pemberian fermentasi jerami jagung diberengi dengan daun gamal sehingga kambing sangat lahap memakannya.

Berdasarkan data pada minggu ke-7 mengalami penurunan (minus) dikarenakan kelalaian dan kurang ketelitian dalam pembuatan fermentasi jerami jagung sehingga kambing kekurangan makanan, sebelumnya fermentasi hanya cukup untuk 1 minggu, pembuatannya selama 2 minggu maka pemberianya dibatasi sedikit-dikit dan dilebihkan pemberian daun gamal pada waktu itu. Maka dari itu jadikan kesalahan yang dilakukan pembelajarn untuk diri kita agar tidak terjadi lagi untuk kedepannya. Berdasarkan cuaca pada waktu itu kurang mendukung, hujan lebat, dan kandang menjadi becek, sehingga kandang berbau menyebabkan kambing batuk-batuk dan juga nafsu makan menjadi berkurang akibatnya pertumbuhan kambing menjadi terhambat. Berdasarkan data minggu selanjutnya pertambahan bobot badan kambing menjadi stabil lagi karena kebutuhannya sudah tercukupi dan nafsu makan sudah meningkat sehingga terjadinya peningkatan bobot badan kambing.

Mengenai kontruksi kandang, sudah cukup baik, kandang tidak terlalu tinggi, ventilasi cukup, dan kandang mengarah cahaya matahari pagi. Menurut [6], kandang yang baik harus memenuhi persyaratan,diantaranya adalah kandang terbut dari bahan yang murah tetapi kuat, pertukaran udara dala kandang berlangsung baik sinar matahari masuk kedalam kandang, kandang mudah dibersihkan, lingkungan kandang bersih, dan tidak banyak dilewati lalu lintas umum.

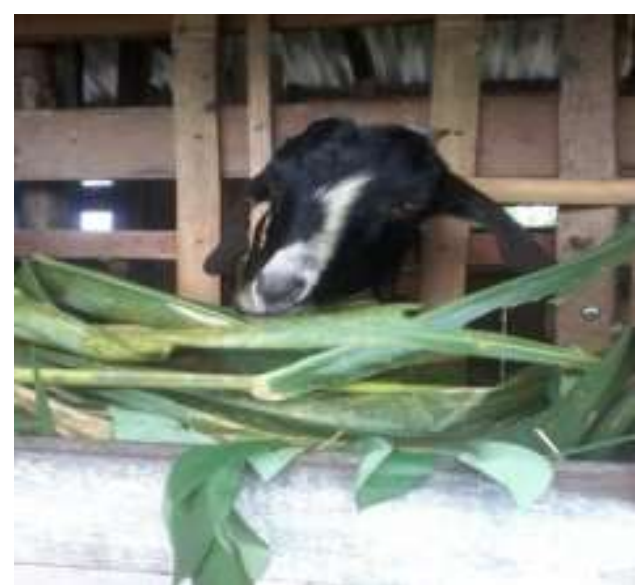

Gambar 1. Kambing memakan jerami jagung

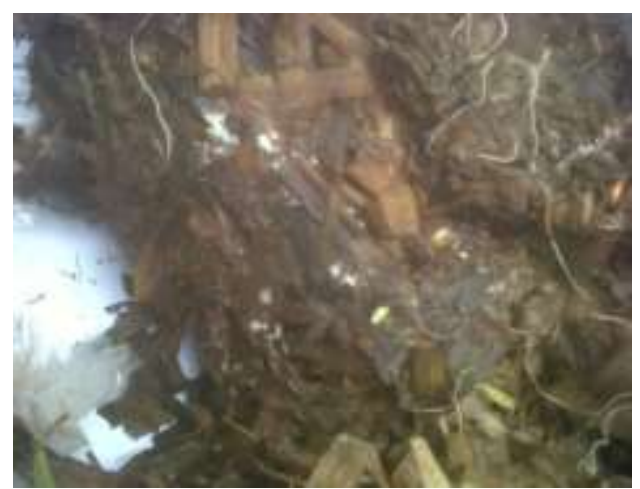

Gambar 2. Fermentasi jerami jagung

\section{Kesimpulan}

Berdasarkan dari hasil penelitian yang dilaksanakan selama 90 hari dapat disimpulkan bahwa, penambahan jerami jagung fermentasi pada pakan ternak kambing perlakuan menghasilkan pertambahan bobot badan kambing lebih tinggi (95,2 g/ekor/hari) dibandingkan dengan kambing kontrol (35,7 g/ekor/hari). 


\section{Daftar Pustaka}

[1] Sarwono, B. 2005. Penggemukan Kambing Potong. Penebar Swadaya. Jakarta.

[2] BPTP Sumatera Barat. 2011. Teknologi Pembuatan Silase Jagung untuk Pakan Sapi Potong. Badan Litbang Pertanian Kementerian Pertanian Republik Indonesia. Sumber: http//sumbar.litbang.pertanian.go.id.

[3] Islamiyati, R. Sjamsuddin, R. Ismartoyo, N. Asmuddin, 2012. Efisiensi Penggunaan Pakan Dan Pertambahan Bobot Badan Kambing Lokal Dengan Pakan Jerami Jagung Yang Diinokulasi Fungi Trichoderma sp.Dan Diperkaya Daun Gamal. Fakultas Peternakan Universitas Hasanudin Makasar.

[4] NRC. 2005. Nutrient Reguirements Of Goats: Angora, Dairy, and Meat Goats In Temperate and Tropical Countries. National Academic Press, Washington, DC.

[5] Sihombing dan Wina, J. 2011. Penggunaan Tape Kulit Buah Kakao Sebagai Pakan Kambing Sedang Tumbuh.

http://repository.usu.ac.id/handle/123456789/250 93

[6] Rianto, E. 2004. Kandang Kambing. Lembaga Pengabdian kepada Masyarakat. Universitas Diponegoro. Semarang 